\title{
Proposal for a model for the development of medium sized urban solid waste Recycling companies, in the municipality of Centro Tabasco
}

\section{Propuesta de un modelo de desarrollo de las medianas empresas recicladoras de residuos sólidos urbanos, en el municipio de centro Tabasco}

MENDOZA-WILSON, Ángela del Carmen†๋*, PÉREZ-PÉREZ, Iris Cristel, ELISEO-DANTÉS, Hortensia and GARCÍA-REYES David Antonio

Tecnológico Nacional de México/Instituto Tecnológico de Villahermosa

ID $1^{\text {st }}$ Author: Ángela del Carmen, Mendoza-Wilson / ORC ID: 0000-0003-4228-725X, CVU CONACYT ID: 914348

ID $1^{\text {st }}$ Coauthor: Iris Cristel, Pérez-Pérez / ORC ID - 000-0003-3120-5597, Researcher ID Thomson: G-1891-2018, CVU CONACYT ID: 843577

ID $2^{\text {nd }}$ Coauthor: Hortensia Eliseo-Dantés / ORC ID: 0000-0003-4006-4669, CVU CONACYT ID: 411079

ID $3^{\text {rd }}$ Coauthor: David Antonio, García-Reyes / ORC ID: 0000-0002-6083-079X, Researcher ID Thomson: D-4836-2018, CVU CONACYT ID: 883868

DOI: $10.35429 / J A F .2019 .18 .6 .12 .16$

Received March 20, 2019; Accepted June 29, 2019

\begin{abstract}
The valuation of urban solid waste consists of the specific transformation of waste considered as waste, through prior treatment, into reusable resources. In this way, the valuation of Urban Solid Waste is achieved through the processes of reuse, reduction and recycling as well as the collection of them, to transform the traditional management of this waste into integrated systems in a sustainable and friendly way with environment. This document presents an overview of the reality experienced by companies engaged in collection and recycling in the municipality of Centro in the state of Tabasco, to perform a comprehensive analysis of productivity in the current reality that allows obtaining a proposal for development that may be applicable to increase productivity in accordance with the current context, observing in detail the current conditions and taking a prospective of the expected situation in the near future of these companies in the municipality of Centro
\end{abstract}

Urban Solid Waste, Productivity, Model

\begin{abstract}
Resumen
La valorización de los residuos sólidos urbanos consiste en la transformación específica de los residuos considerados como desechos, mediante un tratamiento previo, en recursos reutilizables. De esta manera la valorización de los Residuos Sólidos Urbanos, se alcanza a través de los procesos de reutilización, reducción y reciclaje así como de la recolección de los mismos, para transformar la gestión tradicional de estos residuos en sistemas integrados de forma sustentable y amigable con el medio ambiente. En este documento se presenta un panorama general de la realidad que viven las empresas dedicadas a la recolección y recicladoras en el municipio de Centro en el estado de Tabasco, para realizar un análisis integral de la productividad en la realidad actual que permitan obtener una propuesta de desarrollo que pueda ser aplicable para incrementar la productividad de acuerdo con el contexto actual, observando con detalle las condiciones actuales y tomando una prospectiva de la situación esperada en el futuro cercano de estas empresas en el municipio de Centro.
\end{abstract}

Residuos Sólidos Urbanos, Productividad, Modelo

Citation: MENDOZA-WILSON, Ángela del Carmen, PÉREZ-PÉREZ, Iris Cristel, ELISEO-DANTÉS, Hortensia and GARCÍA-REYES David Antonio. Proposal for a model for the development of medium sized urban solid waste Recycling companies, in the municipality of Centro Tabasco. Journal of Administration and Finance. 2019, 6-18: 12-16

*Correspondence to Author (email: stevaz11@ hotmail.com)

$\dagger$ Researcher contributing first author. 


\section{Introduction}

The valuation of MSW covers the entire stage of its life cycle and takes into account environmental benefits, economic optimization and social agreement within a practical and sustainable system. It will also combine a series of options such as the reuse, recovery and classification of recyclable materials, composting of the organic fraction, biogasification, energy recovery and controlled landfills used only for the final disposal of that fraction of the MSW that cannot be recovered by The above mentioned methods.

The participation of the community in the process of valuing urban waste is of paramount importance for the success of this task. The Municipal Governments working jointly with the Non-Governmental Organizations can organize this participation.

The problem facing our country in the area of solid waste, is of great social, economic and health impact since it includes the insufficiency of economic and human resources as well as the deficit in functional structures of operation, lack of understanding of the problem with a integral approach; absence of environmental education and training programs, in addition to the lack of adequate infrastructure and technology among other factors.

In Mexico, the management of MSW is carried out at the municipal level in a traditional way, without this having the best financial, legal, physical and technical infrastructure of human resources. For this reason it is considered that the traditional management of MSW in Mexico is not optimal and requires a rapid incorporation of priority activities such as minimization and recycling.

\section{Method Description}

\section{Generalities}

Integral Solid Waste Management (GIRS) is a methodology (Tchobanoglous, 1994), where solid waste is handled for its reduction, recycling, transformation and disposal, as well as the systematic and determined control of functional elements such as its generation, handling, collection, separation, processing and transformation, transfer, transport, discharge and recovery of land postclause landfill.

\section{Study area}

The research is carried out in the municipality of the Center in the state of Tabasco, capital of the state.



Figure 1 Research methodology Source: Researcher

\section{Method}

The methodology used figure no. 1, it is observed that different tools were used during the development of this research that were: a) information search and retrieval, used to gather information about the elements that integrate the context of the study area; b) exploratory, its application contributed to the location and knowledge of resources; c) multicriteria analysis, its methodological phases allowed to obtain the perception of the actors involved, of the companies and of the authorities, about the local viability of the recycling companies; d) Survey, through the application of randomly semi-structured questionnaires, statistical data were obtained about the different wastes generated in the entity and their possible use. As seen in figure no. two.

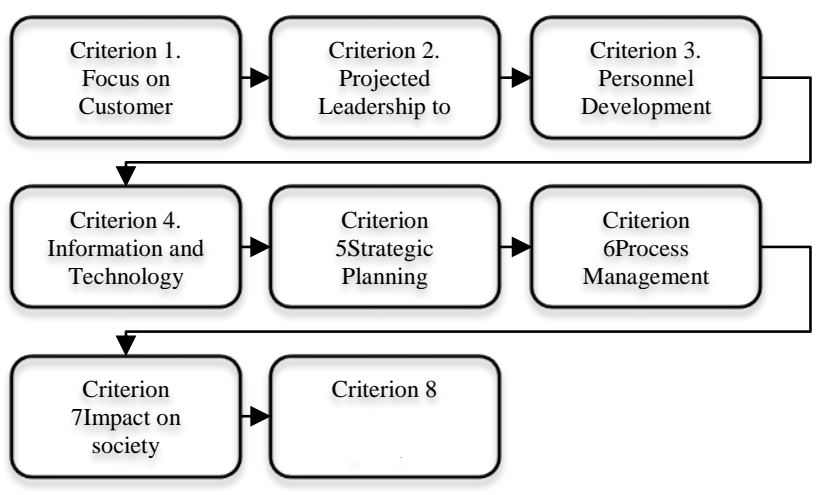

Figure 2 Proposed productivity model Source: Researcher 


\section{Focus on customer satisfaction}

In this criterion, the system used to know and anticipate the needs of customers during the sale and after sale is examined to meet the objective of customer loyalty.

\section{Leadership projected to competitiveness}

This module examines the impact of senior management participation mainly in the process of continuous improvement towards total quality, as well as its vision, commitment in the way it designs and inspires the inclusion of staff and long-term projections.

\section{Staff development and intellectual capital management}

This point is essential as it examines the systems and practices used by the organization to enhance the skills and attitudes of staff through training to develop intellectual capital, as well as job design, incentive systems and recognition for motivation. together as health and wellness promotion.

\section{Information and technology management}

This criterion examines the tools used to safeguard information and design systems for information management of technology and security measures.

\section{Strategic planning}

This criterion examines the planning process and the objectives that are established as well as the strategies for achieving them and if they fulfill the task of raising the organization's performance and its competitive position.

\section{Management and process improvement}

In this criterion, the key elements of the quality management system are examined, such as the design, planning, improvement and standardization of essential and support processes and their evaluation.

\section{Impact on society}

This criterion examines how the organization implements its responsibility with society by making continuous improvement efforts in its locality contributing to other organizations develop quality programs.

\section{Results}

This module analyzes the interrelation between the fundamental indicators of the organization and the value created by maturity as the quality of its processes and systems; employees and suppliers in the internal value chain and for their clients, the sectors of influence and society, in their social value chain.

\section{Productivity}

For decades and nowadays, what is most settled are the profound changes in the economic environment, mainly due to structural changes in the economic, technological, political and therefore in society sectors.

As a consequence of these changes: globalization and the free market and as a counterpart the productivity that has emerged along with these changes and that seems to be a determining factor to succeed in the free market. Productivity began to be present from the time of classical economists such as Adam Smith (1776) and David Ricardo (1817), who emphasized producing at low costs and the differences between the production conditions of the countries and in the differentiated position of production factors, this theorist considered international trade always beneficial for the country that had production costs were lower than the other country with which it is traded.

On the other hand, in more recent times we have Bordas (1993). For this author, productivity is the ability to achieve their objectives, in a way that is higher than the average of the reference sector and in a sustainable way, that is; ability to obtain returns on investments above average, reasonably and ability to do so with low social and environmental costs. Productivity must be addressed beyond competition, as it is not only about imposing itself, but about doing it with superior qualities. This competitive superiority will depend on the peculiarities of each particular industry; of the structure of the market and of the general conditions of the environment in which the companies operate.

\section{Dependent variable}

The productivity of the organization of mediumsized recycling companies in the municipality of Centro, Tabasco. 


\section{Independent variables}

The variables that were analyzed during the investigation are: technological, political, social, environmental, cultural and economic to specify the factors that affect the productivity of the recycling companies in the municipality of $\mathrm{El}$ Centro, Tabasco.

\section{Leadership}

The business sectors are in a very complex time when it is required to be interdependent and interconnected. Companies are most in need of a vision and a goal, the vision makes us know who we are (the purpose), where we are going (our ideal future) and what motivates our trip (values), is where leadership begins to make sense.

According to Ken Blanchard's definition, leadership is the ability to influence people and organizations to unlock their full potential and this results in greater good for all.

\section{Characteristics of Business Leadership:}

$\begin{array}{lll}- & \text { Good communication skills } \\ - & \text { Good team motivation } & \\ - & \text { Charisma } \\ - & \text { Enthusiasm } \\ - & \text { Resolution capacity } \\ - & \text { Organization and ability to manage } \\ & \text { resources } \\ - & \text { Future vision } \\ - & \text { Bargaining power } \\ - & \text { Creativity } \\ - & \text { Discipline } \\ - & \text { Active listening } \\ - & \text { Honesty } \\ - & \text { Strategy } \\ - & \text { Ability to make decisions }\end{array}$

\section{Organizational culture}

Today's organizations are increasingly betting on being an inclusive organization by making their members feel part of it sharing the same culture. The importance of culture is based on the fact that this is the set of values, beliefs, knowledge and ways of thinking that guide, that the members of the organization share and that are transmitted from generation to generation.
On the other hand, values are the basis of organizational culture, define success in concrete terms for workers and set standards for the organization. They inspire the raison d'être of each organization, the objectives to be pursued and the goals to be achieved.

Manuel Gross defines the organizational culture as the set of perceptions, feelings, attitudes, habits, beliefs, values, traditions and forms of interaction within and between existing groups in all organizations.

Culture is transmitted over time and adapts according to external influences and internal pressures resulting from organizational dynamics.

\section{Organizational climate}

The "work environment" is the human and physical environment in which daily work takes place. It influences satisfaction and therefore productivity. Within that context, the organizational climate refers to the set of characteristics of the work environment perceived by the employees and assumed as the main factor influencing their behavior.

Climate factors strongly suggest the way in which the management process is developed in the company as it is a variable that affects its results; Thus, productivity, quality, creativity and people's satisfaction have to do with the weather. The work environment is key to the success of a company because it conditions the attitudes and behavior of its workers.

\section{Learning Organizations}

The concept of organization they learn is increasing given the increasing complexity and uncertainty of the organizational environment, as Peter Senge himself (1990) points out: "The proportion to which organizations learn can become the only sustainable source of competitive advantage".

\section{Strategic Planning}

The main concept of the strategic planning process is the vision: a mental representation of the strategy that exists in the leader's mind and serves as an inspiration or idea that guides what the entire organization should do. 
The CEO or general manager of the organization must lead the visionary process of strategy formulation. He must act as a true internal entrepreneur, who works with subjective aspects, such as intuition, judgment, experience and some personal criteria.

\section{Corporate social responsibility}

When we talk about Corporate Social Responsibility we are going to find a great abundance of concepts, however, regardless of what is adopted, they all agree on the need to promote ethical and responsible behavior, in the face of society and stakeholders.

\section{Below are some of the mostly accepted concepts}

"CSR refers to a business vision that incorporates respect for ethical values, people, communities and the environment. CSR is a broad set of policies, practices and programs integrated in the business operation that support the decision-making process and are rewarded by the administration ". Forum of Business and Social Responsibility in the Americas.

\section{Summary of Results}

The results of the evaluation of the most representative materials of the MSW present in the study area, the following are observed: fast fermentation residues with $24.4 \%$, fine residue with $14.6 \%$, disposable diaper with $12.0 \%$, plastics with $11.5 \%$, paper and cardboard with $11.4 \%$, others with $9.8 \%$, metals with $4.6 \%$ and the rest considered trivial with $11.7 \%$. In contrast, the composition of the MSW by volume corresponds to plastics with $45.6 \%$, paper and cardboard with $20 \%$, disposable diaper with $5.8 \%$, others with $5.1 \%$, metals with $5 \%$, fast fermentation residues with $3.8 \%$, fine waste with $2.2 \%$, vegetable fiber with $2.0 \%$ and trivial with $10.5 \%$.

\section{Conclusions}

The deficiency of the economic resources destined to the collection and clean service significantly affects the Management of Urban Solid Waste in the study area, since it causes the population $(29 \%)$ to resort to their incineration. It is important to take into account the socioeconomic and cultural situation of the area, since this will define the level of management that can be achieved in this place.
Therefore, the productivity potential of the companies under study is very high considering the elements mentioned during the study. With what we can conclude that productivity in these types of companies can be significantly increased in the medium and long term.

Although the population claims to be willing to separate recyclable materials, the lack of proper handling of them by the city council weakens this possibility in the short term. The study area presents the characteristics of a traditional solid waste management, a situation that is no longer convenient at present because of the problem it represents in all aspects. Therefore, the hierarchy in the integral management of MSW of the minimization and recycling processes is necessary. Certainly in each environment there are different possibilities and limitations, so it is important to have an orderly and complete vision of the alternatives. From it you can plan efficiently towards viable solutions.

It is recommended that, according to the socio-economic and cultural characteristics of the study area, a comprehensive management of shared MSW between municipalities, that is, regional under the hierarchy of minimization, is managed, it is also important to consider the installation of a common landfill with its respective transfer stations, and paper and PET collection centers.

\section{References}

Acurio, G. A. (1997). Diagnóstico de la Situación del Manejo de Residuos Sólidos Municipales en América Latina y el Caribe. Washington, D.C.: Organización Panamericana.

Chávez de la Peña, V. (2019). Plan de manejo integral de residuos sólidos en el Tecnológico de Monterrey. Monterrey, Nuevo León.

Del Castillo Pomares, G. S. (2019). Programa de prácticas socio culturales para el adecuado manejo de residuos sólidos en el centro poblado Túpac Amaru, Lagunas, Chiclayo, 2018. Túpac Amaru, Lagunas, Chiclayo.

Palacio Cáceres, L. J. (2018). Propuesta de proyecto de emprendimiento social para la empresa Ser Ambiental SAESP orientada a mejorar las condiciones laborales y sociales de los recicladores de la ciudad de Girardot.

MENDOZA-WILSON, Ángela del Carmen, PÉREZ-PÉREZ, Iris Cristel, ELISEO-DANTÉS, Hortensia and GARCÍA-REYES David Antonio. Proposal for a model for the development of medium sized urban solid waste Recycling companies, in the municipality of Centro Tabasco. Journal of Administration and Finance. 2019 